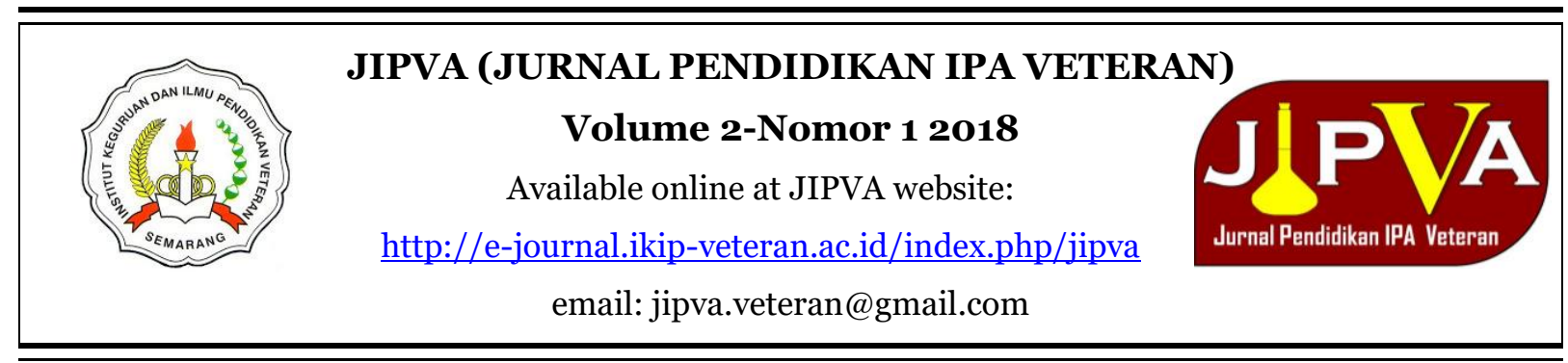

\title{
MENGUKUR KEMAMPUAN BERPIKIR ANALITIS DAN KETERAMPILAN PROSES SAINS MAHASISWA CALON GURU FISIKA STKIP AL HIKMAH SURABAYA
}

Faiz Hasyim

Pendidikan Fisika, STKIP Al Hikmah Surabaya

email: faiz.stkiph@gmail.com

\begin{abstract}
Abstrak
Penelitian ini bertujuan memetakan penguasaan kemampuan berpikir analitis dan keterampilan proses sains mahasiswa calon guru fisika. Penelitian ini merupakan penelitian deskriptif kualitatif. Penelitian ini dilakukan terhadap mahasiswa calon guru fisika STKIP Al Hikmah Surabaya. Teknik pengumpulan data menggunakan data kemampuan awal mahasiswa dan teknik tes kemudian data dianalisis menggunakan teknik analisis secara deskriptif. Hasil penelitian menunjukkan bahwa penguasaan kemampuan berpikir analitis dan keterampilan proses sains mahasiswa calon guru fisika STKIP Al Hikmah Surabaya terbagi dalam tiga level yaitu level tinggi sebanyak 33\%, level sedang sebanyak 50\%, dan level rendah sebanyak $17 \%$. Penguasaan keterampilan berpikir untuk masing-masing kriteria adalah satu kriteria berada pada kategori tinggi, dua kriteria berada pada kategori sedang, dan satu kriteria berada pada kategori rendah.

Kata kunci: kemampuan berpikir analitis, keterampilan proses sains, mahasiswa calon guru fisika.

\section{MEASURING PRE-SERVICE PHYSICS TEACHERS' ANALYTICAL THINKING} ABILITY AND SCIENCE PROCESS SKILLS OF STKIP AL HIKMAH SURABAYA

Abstract

This research is designed to classify pre-service physics teachers' analytical thinking ability and science process skills. It is a descriptive qualitative research. This research was conducted on pre-service physics teachers of STKIP Al Hikmah Surabaya. Data collection technique used in this research was the result of students' pretest and test, afterwards the data were analyzed using descriptive analysis technique. The result shows that the pre-service physics teachers' analytical thinking ability and science process skills of STKIP Al Hikmah Surabaya is divided into three level, those are high level (33,3\%), moderate level (50\%), and low level (16,7\%). The proficiency of thinking skill ability for each criterion is divided into three categories: first, a criterion is considered as high category; second, two criteria are considered as medium category; and third, one criterion is considered as low category.
\end{abstract}

Keywords: analytical thinking ability, science process skills, pre-service physics teacher. 


\section{PENDAHULUAN}

Sebuah negara yang maju pasti akan menjadikan pendidikan sebagai unsur utama dalam skala prioritas baik anggaran, SDM, maupun infrastrukturnya. Sesuai dengan tujuan pendidikan nasional, mencerdaskan kehidupan bangsa menjadi salah satu variabel yang tidak bisa dipandang sebelah mata. Pembangunan suatu negara dapat dikatakan berhasil jika memiliki Sumber Daya Manusia (SDM) yang berkualitas. Hasyim (2015) mengatakan bahwa pembangunan dibidang pendidikan merupakan usaha untuk mencerdaskan suatu bangsa khususnya untuk peningkatan penguasaan ilmu pengetahuan dan teknologi dengan tujuan meningkatkan kualitas SDM. Implikasinya, hal ini dapat meningkatkan kualitas suatu bangsa.

Surapranata (2005) berpendapat bahwa kurikulum, proses pembelajaran, dan penilaian tiga dimensi penting dalam pendidikan. Antara satu dimensi dengan dimensi yang lain saling berhubungan. Kurikulum menjadi sangat penting karena merupakan turunan dari tujuan pendidikan, sedangkan proses pembelajaran juga sangat penting karena merupakan usaha yang dilakukan oleh guru dalam mencapai tujuan pendidikan. Senada dengan kedua dimensi di atas, penilaian sebagai parameter tercapainya tujuan pembelajaran. Oleh karena itu, keberhasilan pencapaian tujuan pendidikan tidak hanya tergantung pada kurikulum dan proses pembelajaran saja tapi penilaian juga menjadi tolak ukur keberhasilan. Hasil penilaian ini haruslah mengungkapkan informasi secara lengkap dan sesuai dengan data yang diperlukan, sedangkan hasil penilaian yang sesuai bisa diperoleh hanya menggunakan instrumen penilaian yang tepat.

Dalam proses pembelajaran sains khususnya fisika, harus memenuhi karakteristik pembelajaran fisika. Mundilarto (2010) dalam bukunya menjelaskan bahwa fisika sebagai ilmu dasar memiliki karakteristik yang mencakup bangun ilmu yang terdiri atas fakta, konsep, prinsip, hukum, postulat, dan teori serta metodologi keilmuan. Fisika merupakan ilmu yang terbentuk melalui prosedu baku atau biasa disebut sebagai metode ilmiah. Salah stau urutan

Kemampuan berpikir analitis merupakan domain ke empat dari revisi Taksonomi Bloom. Derivasi dari kemampuan ini salah satunya adalah kemampuan untuk menganalisis suatu masalah. Penjelasan detail terkait kemampuan berpikir analitis menurut Anderson \& Krathwohl (2010) bahwa kemampuan menganalisis mencakup belajar untuk menentukan potongan-potongan informasi yang relevan atau penting (membedakan), menentukan cara-cara untuk menata potongan-potongan informasi tersebut (mengorganisasikan), dan menentukan tujuan dibalik informasi itu (mengatribusikan). Penjelasan tersebut di atas dapat diketahui bahwa kemampuan menganalisis terbagi dalam tiga kategori yaitu membedakan, mengorganisasikan, dan mengatribusikan. Rustaman (2005) mengupas taksonomi Bloom khususnya kemampuan analitis ditandai dengan beberapa kata kerja operasional yaitu: memecahkan, membuat diagram, membedakan, memisahkan, mengidentifikasi, menggambarkan, menarik kesimpulan, membuat garis besar/menginferensi, menunjukkan, menghubungkan, memilih, memisahkan, dan mendeskripsikan/merinci.

Dari beberapa pendapat di atas, maka dapat ditarik kesimpulan bahwa kemampuan analitis adalah suatu kemampuan peserta didik untuk menguraikan suatu hal ke dalam bagian-bagiannya dan dapat mencari 
keterkaitan antara bagian-bagian tersebut. Kemampuan berpikir analitis ditandai dengan beberapa kata kerja operasional seperti yang sudah dijelaskan sebelumnya. Dalam penelitian ini, pengukuran kemampuan berpikir analitis yang dipilih empat kemampuan yang sesuai dengan keterampilan proses yang dipilih yaitu mengorganisasikan, menganalisis, membuat garis besar, dan mendeskripsikan.

Prasetyo, et. al (2011) mengatakan bahwa penguasaan natural sains melalui pembelajaran secara teoritis sangat ditentukan oleh kemampuan dan kreatifitas peserta didik dalam menguasai keterampilan proses sains. Dalam pembelajaran fisika, peserta didik dituntut untuk aktif. Peserta didik tidak hanya diam menerima materi secara teori yang diberikan oleh guru tanpa mengetahui proses yang dilakukan dalam menemukan suatu konsep. Pembelajaran fisika seharusnya berupa proses untuk menemukan suatu gejala dengan melibatkan etika dan keterampilan.

Keterampilan proses sains diangkat sebagai kemampuan yang terintegrasi pada materi pelajaran, artinya keterampilan proses sains sama pentingnya dengan konsep sains. Pada pembelajaran sains menekankan pada pemberian pengalaman belajar secara langsung dengan mengembangkan keterampilan proses sains agar mahasiswa calon guru fisika dapat menjelajahi dan memahami fenomena alam. Selain itu, penggunaan dan pengembangan keterampilan proses sains dan sikap ilmiah dalam pembelajaran sains bertujuan agar mahasiswa calon guru fisika mampu memahami konsep-konsep dan mampu memecahkan masalah sains.

Keterampilan proses sains menurut Rustaman (2005) dibagi menjadi sembilan indikator yaitu: melakukan pengamatan, menafsirkan pengamatan atau inferensi, mengelompokkan atau klasifikasi, prediksi/meramalkan,berkomunikasi/ mengkomunikasikan hasil, berhipotesis, merencanakan percobaan, menerapkan konsep, dan mengajukan pertanyaan. Dalam penelitian ini, keterampilan proses sains yang akan diukur terbatas dalam empat kriteria saja yaitu keterampilan merencanakan percobaan, keterampilan memprediksi, keterampilan menginferensi, dan keterampilan mengkomunikasikan hasil.

Sudijono (2007) sudah menjelaskan bahwa kemampuan analisis adalah kemampuan untuk menguraian atau merinci keadaan ke bagian yang lebih kecil serta dapat memahami hubungan antarbagian tersebut. Dari pernyataan tersebut menunjukkan bahwa kemampuan berpikir analitis sangat cocok untuk menyajikan soal fisika khususnya pokok bahasan elastisitas, karena pada pokok bahasan ini membutuhkan kejelian mahasiswa calon guru fisika dalam penyelesaian soal. Selain itu, keterampilan proses sains juga tidak bisa lepas dalam penyampaian pokok bahasan tersebut. Misalnya dalam praktikum hukum Hooke, mahasiswa calon guru fisika dituntut untuk menggunakan keterampilan prosesnya dalam melakukan serangkaian percobaan. Dari pembahasan di atas, dapat disimpulkan keterampilan proses sains dan kemampuan berpikir analitis tidak bisa terlepas satu sama lain dalam memahami pokok bahasan elastisitas, sehingga sangat diperlukan integrasi kedua variabel ini.

Usman (2006) mengatakan bahwa selain dengan pengamatan langsung, keterampilan proses sains memang dapat dilakukan dengan cara tes tertulis. Oleh karena itu untuk melihat hasil belajar peserta didik yang akurat dan mencapai dua sasaran pencapaian sekaligus (keterampilan proses 
sains dan kemampuan berpikir analitis), diperlukan sebuah integrated assessment yang dapat mengukur keterampilan proses sains dan kemampuan berpikir analitis peserta didik SMA.

Dalam penelitian yang dilakukan Nuangchalerm (2009) menyatakan bahwa hasil analisis kemampuan berpikir analitis peserta didik kelas dua yang telah dipelajari melalui kegiatan pembelajaran berbasis penyelidikan dengan bantuan program Wilcoxon Matched Signed-Peringkat Test. Hal ini dapat disimpulkan bahwa skor posttest memiliki skor yang lebih tinggi daripada pretes dengan taraf signifikansi 0,5. Selanjutnya, Husain, et. al (2012) mengadakan penelitian tentang berpikir analitis dan berpikir kritis. Hasil penelitian ini dapat diamati bahwa tingkat keterampilan berpikir kritis dan analitis antara peserta didik rendah. Hanya 2 dari 70 pertanyaan yang diajukan dapat diklaim mengandung unsur berpikir kritis tinggi dan memenuhi kriteria MST. Sebagian besar pertanyaan dapat diklasifikasikan sebagai kategori rendah sinkron dengan rendahnya tingkat kemampuan berpikir kritis.

Penelitian penguasaan keterampilan berpikir kritis dan analitis yang dilakukan McDonald (2012) menghasilkan data penguasaan keterampilan berpikir kritis dan analitis dari 40 tugas akhir hanya 12,5\% yang dikuasai peserta didik. Meskipun masih tergolong rendah dalam penguasaan keterampilan berpikir kritis dan analitis, namun hal ini membuktikan usaha peserta didik dalam menyelesaikan tugas akhir sangat tinggi. Rusou, et. al (2013) melakukan penelitian mengintegrasikan antara intuisi dan berpikir analitis terhadap satu sama lain pada tugas-tugas. Hasil penelitian menunjukkan konsistensi pilihan yang lebih tinggi (transitivitas) saat intuisi dan berpikir analitis dipadukan.
Kemampuan berpikir analitis peserta didik juga diteliti oleh Groothoff, et. al (2008). Dari penelitian ini dapat disimpulkan bahwa kemampuan berpikir analitis berkembang dari waktu ke waktu, namun kemampuan ini perlu dilatih sehingga kemampuannya semakin berkembang. Terbukti bahwa pelatihan untuk meningkatkan kemampuan berpikir analitis dalam waktu yang singkat tidak memberikan efek signifikan. Berbeda jika kemampuan ini dilatih dalam proses yang kontinyu dan terstruktur akan mendapatkan hasil yang lebih bagus.

Sebagai calon guru fisika, pemetaan kemampuan berpikir analitis perlu dilakukan untuk mengetahui keterampilan berpikir tingkat tinggi. Kemampuan analitis merupakan salah satu domain dari keterampilan berpikir tingkat tinggi. Kemampuan berpikir rtingkat tinggi salah satu bekal calon guru fisika menterjemahkan dan mentranformasi konsep fisika ke muridmuridnya.

Dari beberapa sumber di atas, dapat ditarik kesimpulan bahwa menjadi guru fisika harus memiliki keterampilan proses sains dan kemampuan berpikir tingkat tinggi salah satunya kemampuan berpikir analitis. Oleh karena itu, mahasiswa calon guru fisika di semester awal harus sudah dipetakan berdasarkan penguasaan kemampuan berpikir tersebut agar pengembangan mahasiswa calon guru fisika lebih terarah.

\section{METODE}

\section{Jenis Penelitian}

Penelitian ini bertujuan untuk memetakan kemampuan berpikir analitis dan keterampilan proses sains mahasiswa calon guru. Subjek penelitian diberi instrumen tes (Intsrumen Integrated Assessment Fisika) yang sudah 
dikembangkan sebelumnya oleh Hasyim (2015).

Penelitian ini termasuk ke dalam penelitian deskriptif. Cohen, et. al (2000) menjelaskan bahwa penelitian deskriptif adalah penelitian yang mengungkapkan dan menggambarkan suatu peristiwa yang terjadi pada kondisi saat ini. Pendekatan pada penelitian ini adalah pendekatan kualitatif.

\section{Waktu dan Tempat Penelitian}

Penilitian dilakukan pada bulan September 2017. Tempat penelitian adalah di kampus keguruan STKIP Al Hikmah Surabaya.

\section{Subjek Penelitian}

Target penelitian ini adalah mahasiswa calon guru fisika semester 1 . Subjek penelitian ini adalah mahasiswa pendidikan fisika STKIP Al Hikmah Surabaya. Subjek tersebut dipilih atas dasar lokasi dan persebaran asal sekolah mahasiswa.

\section{Prosedur}

Prosedur penelitian ini dilakukan dengan menentukan subjek penelitian terlebih dahulu, mengumpulkan data awal subjek penelitian, dan pengambilan data. Penelitian difokuskan pada pengambilan data berupa hasil tes mengggunakan Intsrumen Integrated Assessment Fisika

Hasil penelitian ini kemudian disinkronkan dengan data kemampuan awal mahasiswa yaitu nilai akademik tes penjaringan mahasiswa baru STKIP Al Hikmah Surabaya.

\section{Data, Intrumen, dan Teknik Pengumpulan Data}

Jenis data yang dikumpulkan dalam penelitian ini yaitu data kualitatif. Teknik pengumpulan data menggunakan teknik tes.

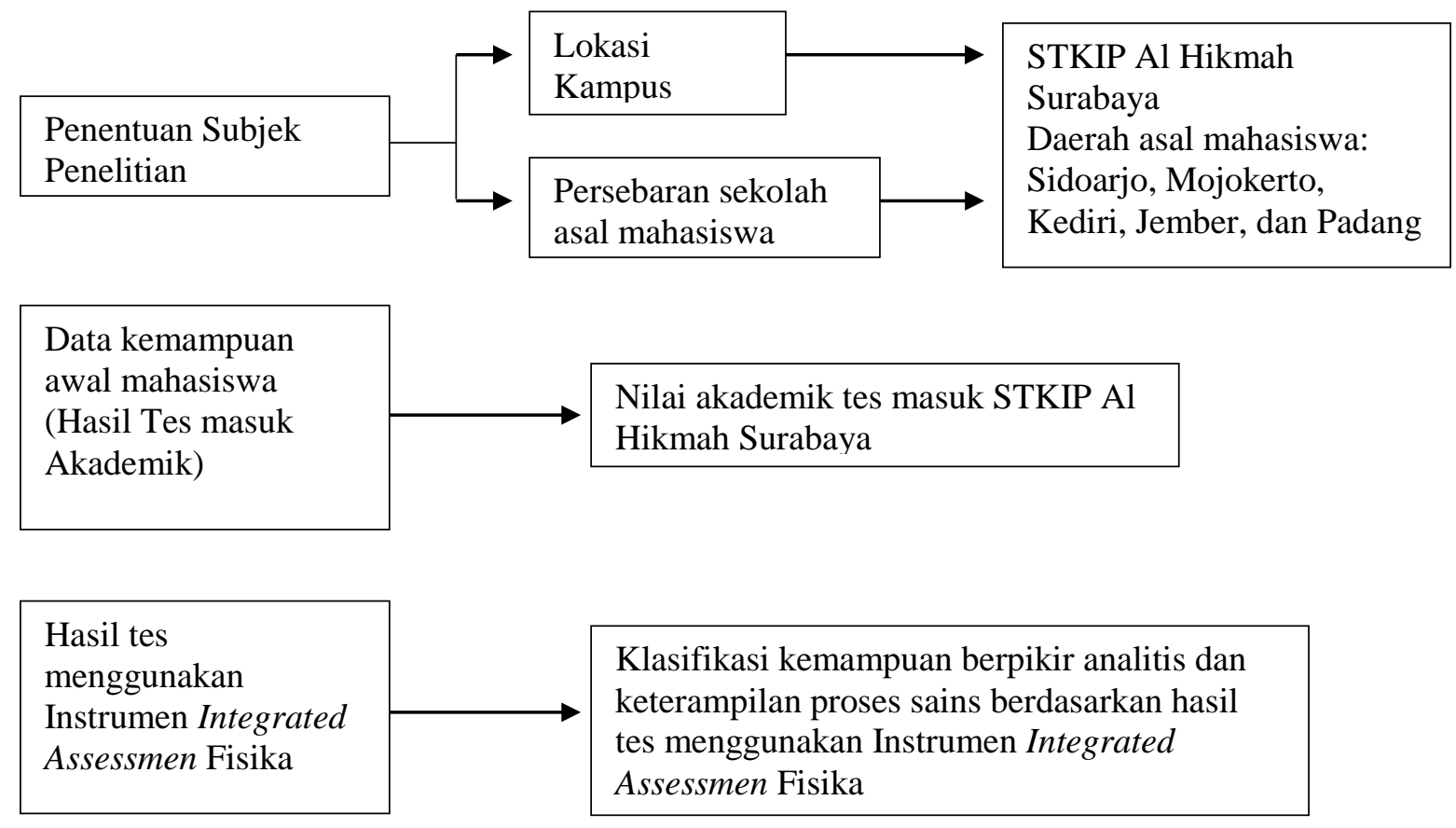

Gambar 1. Diagram Prosedur Penelitian 
Instrumen pengumpul data menggunakan data awal mahasiswa dan instrumen tes yang yang sudah dikembangkan oleh Hasyim (2015) dan sudah diuji validitasnya yaitu Instrumen Integrated Assessmen Fisika.

\section{Teknik Analisis Data}

Teknik analisi data menggunakan teknik analisis data secara deskriptif. Untuk mengetahui tingkat penguasaan kemampuan berpikir analitis dan keterampilan proses sains dikategorikan berdasarkan rata-rata ideal dan simpangan baku ideal. Skor tertinggi ideal adalah skor tertinggi yang mungkin diperoleh dari keseluruhan jawaban soal. Skor terendah ideal ialah skor terendah yang mungkin diperoleh dari keseluruhan jawaban soal. Menurut Sukardjo (2012) lima level kemampuan memiliki rentang seperti pada Tabel 1 . Kelima level tersebut adalah level sangat tinggi, tinggi, sedang, rendah, dan sangat rendah.

Tabel 1. Konversi Nilai Aktual Menjadi Nilai Skala 5

\begin{tabular}{lcl}
\hline Rentang Skor (i) & Nilai & \multicolumn{1}{c}{ Kategori } \\
\hline $\mathrm{x}>\bar{x}+1,80 \mathrm{SBi}$ & $\mathrm{A}$ & Sangat tinggi \\
$\bar{x}+0,60 \mathrm{SBi}<\mathrm{x} \leq \bar{x}+1,80 \mathrm{SBi}$ & $\mathrm{B}$ & Tinggi \\
$\bar{x}-0,60 \mathrm{SBi}<\mathrm{x} \leq \bar{x}+0,60 \mathrm{SBi}$ & $\mathrm{C}$ & Sedang \\
$\bar{x}-1,80 \mathrm{SBi}<\mathrm{x} \leq \bar{x}-0,60 \mathrm{SBi}$ & $\mathrm{D}$ & Rendah \\
$\mathrm{x} \leq \bar{x}-1,80 \mathrm{SBi}$ & $\mathrm{E}$ & Sangat rendah \\
\hline
\end{tabular}

Keterangan :

$\mathrm{X}_{\mathrm{i}}: 1 / 2$ (skor maksimal + skor minimal ideal)

Sbi : 1/6 (skor maksimal ideal-skor minimal ideal).

\section{HASIL DAN PEMBAHASAN}

Penelitian ini bertujuan untuk mengetahui pemetaan penguasaan kemampuan berpikir analitis dan keterampilan proses sains mahasiswa calon guru fisika. Kampus yang digunakan sebagai lokasi penelitian dipilih berdasarkan dua kriteria yaitu 1) lokasi kampus, 2) persebaran asal sekolah mahasiswa.

Lokasi sekolah sebagai subjek penelitian berada di Jawa Timur dan berada di pusat kota Jawa Timur yaitu Kota Surabaya. Selain itu, persebaran daerah asal mahasiswa sudah mencangkup beberapa kota/kabupaten di provinsi Jawa Timur.

Berdasarkan hasil tes, klasifikasi kemampuan berpikir analitis dan keterampilan proses sains mahasiswa calon guru fisika dibagi menjadi tiga kategori berdasarkan adaptasi Sukardjo (2012) seperti pada Tabel 2 .

Tabel 2. Teori Klasifikasi Kemampuan Berpikir Analitis dan Keterampilan Proses Sains

\begin{tabular}{cc}
\hline Kategori & Persentase Skor \\
\hline Rendah & $0 \%>X \geq 33,3 \%$ \\
Sedang & $33,3 \%>X \geq 66,7 \%$ \\
Tinggi & $66,7 \%>X \geq 100 \%$ \\
\hline
\end{tabular}

Berdasarkan hasil pengmbilan data, persentase penguasaaan kemampuan berpikir analitis dan keterampilan proses sains mahasiswa calon guru secara umum terbagi menjadi tiga kelompok besar yang dapat dilihat pada Tabel 3.

Tabel 3. Klasifikasi Kemampuan Berpikir Analitis Mahasiswa Calon Guru

\begin{tabular}{cc}
\hline Kategori & Persentase Skor \\
\hline Rendah & $17 \%$ \\
Sedang & $50 \%$ \\
Tinggi & $33 \%$ \\
\hline
\end{tabular}

Data di atas, peneliti coba sinkronkan dengan data awal subjek penelitian yaitu nilai akademik tes masuk STKIP Al Hikmah seperti pda tabel 4. 
Tabel 4. Nilai Akademik Tes Masuk

Mahasiswa Calon Guru

\begin{tabular}{cc}
\hline Kategori & Persentase Skor \\
\hline Rendah & $33 \%$ \\
Sedang & $50 \%$ \\
Tinggi & $17 \%$ \\
\hline
\end{tabular}

Dari kedua tabel di atas, persebaran kemampuan awal mahasiswa dan hasil penelitian memiliki persebaran yang relatif sama. Mahasiswa yang berada pada kategori sedang sebanyak $50 \%$ dari seluruh jumlah mahasiswa. Prosentase jumlah mahasiswa yang memiliki kemampuan rendah dan tinggi yaitu antara $33 \%$ dan $17 \%$. Hal ini dapat diinterpretasikan bahwa pemetaan kemampuan berpikir analitis dan keterampilan proses sains mahasiswa calon guru tidak jauh dari data awal mahasiswa. Hasil ini yang akan menjadi pijakan dalam menghasilkan lulusan guru fisika yang berkualitas dan memiliki kompetensi yang dibutuhkan di lapangan.

Penguasaaan kemampuan berpikir analitis masing-masing indikator yang dikuasai mahasiswa calon guru fisika dapat dilihat pada Gambar 2 sedangkan penguasaan keterampilan proses sains dapat dilihat pada Gambar 3.

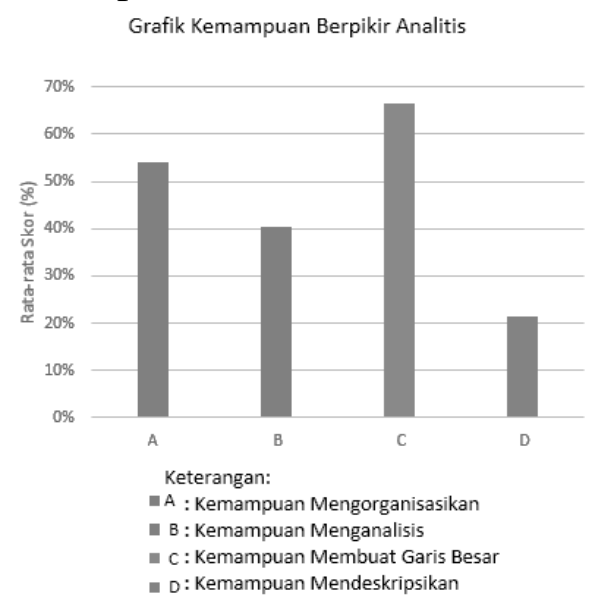

Gambar 2. Rata-Rata Penguasaan

Kemampuan Berpikir Analitis
Gambar 2 memberi informasi bahwa berdasarkan teori yang diadaptasi dari Sukardjo (2012) dari empat kemampuan berpikir analitis yang diukur, rata-rata prosentase penguasaan kemampuan berpikir analitis mahasiswa calon guru fisika berada pada posisi sedang. Hal ini dapat ditarik kesimpulan bahwa sebenarnya input mahasiswa calon guru fisika secara keseluruhan cukup bagus.

Dari grafik yang disajikan dalam gambar 2 dapat dilihat bahwa penguasaan kemampuan membuat garis besar mahasiswa calon guru merupakan kemampuan yang paling tinggi. Kemampuan ini mendukung mahasiswa lebih mudah dalam menarik kesimpulan dari permasalahan-permasalahan fisika. Kemampuan mengorganisasikan dan menganalisis berada pada kategori sedang, walaupun penguasaan kemampuan mengorganisasikan cenderung lebih tinggi daripada kemampuan menganalisis. Kemampuan ini yang akan membekali mahsiswa bagaimana menganalisis fenomena alam sehingga bisa diinterpretasikan ke dalam konsep-konsep fisika. Penguasaan kemampuan mendeskripsikan merupakan kemampuan yang paling lemah yang dimiliki oleh mahasiswa calon guru fisika. Sehingga, jika ditarik kesimpulan penguasaan kemampuan berpikir analitis mahasiswa calon guru ada satu kriteria yang paling dikuasai, dua kriteria cukup dikuasai, dan satu kriteria kurang dikuasai yaitu kemampuan mendeskripsikan sesuatu.

Pada dasarnya hampir semua penguasaan kemampuan berpikir analitis secara rata-rata masuk kategori sedang. Hal ini dapat ditarik benang merah dari hasil tes akademik seperti yang sudah dipaparkan di depan. Proses perkuliahan kedepan seharusnya lebih menitikberatkan pada 
keterampilan berpikir yang cenderung rendah. Dalam hal ini adalah ketampilan berpikir mendeskripsikan sesuatu. Akan tetapi, porsi untuk melatih kemampuan mengorganisasikan dan kemampuan menganalisis juga memiliki porsi yang cukup diberikan kepada mahasiswa calon guru. Sistem perkuliahan yang lebih menitikberatkan peningkatan kemampuan berpikir tingkat tinggi sangat diperlukan, apalagi menyiapkan calon guru fisika masa depan.

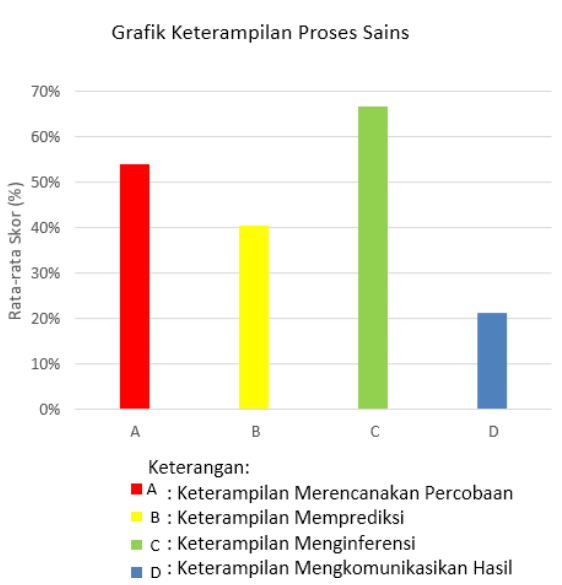

Gambar 3. Rata - Rata Penguasaan

Keterampilan Proses Sains

Gambar 3. di atas merupakan gambaran penguasaan keterampilan proses sains mahasiswa calon guru. Grafik di atas memberi informasi bahwa penguasaan keterampilan menginferensi merupakan keterampilan yang paling dikuasai subjek penelitian. Keterampilan mengkomunikasikan hasil adalah keterampilan proses sains yang kurang dikuasai mahasiswa calon guru. Padalah keterampilan ini sangat dibutuhkan oleh seorang guru fisika, bagaimana bisa menginterpretasi data yang disajikan dalam sebuah grafik. Jika keterampilan ini tidak diasah dengan baik, mahasiswa calon guru fisika kurang dapat menyajikan data-data hasil percobaan dalam laporan. Keterampilan yang memiliki nilai hampir sama adalah keterampilan merencanakan percobaan dan ketrampilan memprediksi walaupun keterampilan merencanakan percobaan cenderung lebih tinggi nilainya daripada ketrampilan memprediksi. Kedua keterampilan ini cukup dikuasai mahasiswa calon guru sehingga mahasiswa calon guru dalam menghadapi praktikum-praktikum pada nantinya tidak terlalu kesulitan. Kompetensi ini ditambah dengan kemampuan memprediksi, mahasiswa dapat lebih kritis dan kreatif dalam menghadapi persoalan-persoalan fisika.

Dari hasil penelitian di atas, menginformasikan bahwa penguasaan keterampilan berpikir analitis dan keterampilan proses sains sangat dibutuhkan oleh mahasiswa calon guru, terlebih calon guru fisika. Menjadi guru fisika tidaklah cukup faham materi saja, namun proses pemahaman ini disertai dengan peningkatan kemampuan berpikir yang memadai sehingga hal ini akan menjadi bekal saat menjadi guru fisika. Keterampilan proses sains merupakan bagian yang tak terpisahkan dari seorang saintis, termasuk di dalamnya guru fisika. Karena, dengan skill ini, mahasiswa bisa menemukan hal-hal baru dengan metode yang jelas serta terukur. Berdasarkan penelitian ini, dihasilkan sejauh mana pengusanaan kemampuan berpikir analitis dan keterampilan proses sains mahasiswa. Dari pemetaaan inilah, pembelajaran fisika dapat dikonsentrasikan pada kekurangan mahasiswa tersebut. Hal ini sejalan dengan penelitian yang dilakukan oleh Hasyim (2015) bahwa pemetaan keterampilan berpikir analitis dan keterampilan proses sains peserta didik hendaklah dilakukan sedini mungkin untuk menentukan pola pembelajaran fisika pada peserta didik selanjutnya. 


\section{SIMPULAN DAN SARAN}

Simpulan

Hasil pengukuran kemampuan berpikir analitis dan keterampilan proses sains mahasiswa calon guru fisika tersebar menjadi tiga level, yaitu $17 \%$ berada pada level rendah, 50\% pada level cukup, dan sebanyak $33 \%$ pada level tinggi.

Penguasaan keterampilan berpikir untuk masing-masing kriteria adalah satu kriteria berada pada kategori tinggi, dua kriteria berada pada kategori sedang, dan satu kriteria berada pada kategori rendah.

\section{Saran}

Saran yang dapat direkomendasikan adalah tindak lanjut dalam perkuliahan di sesuaikan dengan kondisi mahasiswa. Proses perkuliahan fisika yang akan berlangsung berawal dari peningkatan kemampuan berpikir yang kurang dikuasai mahasiswa. Hal ini dilakukan agar lulusan calon guru fisika menguasai kemampuan berpikir tingkat tinggi (kemampuan berpikir analitis) dan keterampilan proses sains. Jika semua kebutuhan dalam peningkatan kemampuan berpikir analitis dan keterampilan proses sains tercukupi, maka subjek penelitian akan menjadi guru yang mampu mengajarkan materi fisika secara komprehensif dan kreatif. Penelitian ini sangat disarankan diduplikasi kampus lain sebagai upaya memetakan kemampuan awal mahasiswa khususnya mahasiswa pendidikan fisika. Hal ini dapat menjadi pijakan dalam proses pembelajaran fisika yang akan dilakukan pada tahap selajutnya.

\section{DAFTAR PUSTAKA}

Anderson, L.W., \& Krathwohl, D.R. (2010). Kerangka landasan untuk pembelajaran, pengajaran, dan asesmen: Revisi taksonomi pendidikan bloom. (Terjemahan Agung
Prihantoro). New York: Addison Wesley Longman, Inc. (Buku asli diterbitkan tahun 2001).

Cohen, Louis., Manion, Laurence., \& Morrison, Keith. (2000). Research Mehtods in Education. London: Routledge Falmer.

Groothoff, J.W., Frenkel, J., Tytgat, G.A.M., et. al, (2008). Growth of analytical thinking skills over time as measured with the MATCH test. Journal of Medical Education, 42, 1037-1043. Diambil pada tanggal 14 Mei 2015, dari http://eds.b.ebscohost.com/eds/detail /detail?sid=a85894bf-9815-4a469385.

Hasyim, Faiz. (2015). Pengembangan Instrumen Integrasted Assessment Fisika untuk Mengukur Keterampilan Proses Sains dan Kemampuan Berpikir Analitis Peserta Didik SMA pada Pokok Bahasan Elastisitas. Thesis, tidak dipublikasikan. Universitas Negeri Yogyakarta.

Husain, H., Mokri, S.S., Hussain, A., et. al, (2012). The level of critical and analytical thinking skills among electrical and electronics engineering students. Journal of Asian Social Science, 8, 80-87. Diambil pada tanggal 14 Mei 2015, dari http://search.proquest.com/docview/ 1346923175/BF201.

McDonald, G. (2012). Teaching critical \& analytical thinking in high school biology. Journal of The American Biology Teacher, 74, 178-181. Diambil pada tanggal 14 Mei 2015, dari http://search.proquest.com/docview/ 947862175/BF201ED45A9C41E0P Q/8?Ac.. 
Mundilarto.(2010). Penilaian hasil belajar fisika. Yogyakarta: Pusat Pengembangan Instruktional Sains.

Nuangchalerm, P. (2009). Cognitive development, analytical thinking and learning satisfaction of second grade students learned through inquirybased learning. Journal of Asian Social Science, 5, 82-87. Diambil pada tanggal 17 Mei 2015, dari http://www.eric.ed.gov/contentdelive ry/servlet/ERICServlet?accno=ED50 $\underline{6511}$.

Prasetyo, Z. K., Senam, Wilujeng, I., et. al, (2011). Pengembangan perangkat pembelajaran sains terpadu untuk meningkatkan kognitif, keterampilan proses, kreativitas serta menerapkan konsep ilmiah peserta didik SMP. Laporan Penelitian. UNY.

Rusou, Z., Zakay, D., \& Usher, M. (2013). Pitting intuitive and analytical thinking against each other: The case of transitivity. Journal of Psychonomic Bulletin \& Review, 20, 608-614. Diambil pada tanggal 17 Mei 2015, dari http://eds.b.ebscohost.com/eds/detail /detail?sid=73c86b3325674929ac4b31d4e9f 1 b02f.

Rustaman, N. (2005). Strategi belajar mengajar biologi. Malang: UM Press.

Sudijono, A. (2007). Pengantar evaluasi pendidikan. Jakarta: PT. Raja Grafindo Persada.

Sukardjo. (2012). Evaluasi pembelajaran IPA. Yogyakarta: UNY.

Surapranata, S. (2005). Panduan penulisan tes tertulis: Implementasi kurikulum 2004. Bandung: Remaja Rosdakarya.

Usman, M. U. (2006). Menjadi guru profesional. Bandung: PT Remaja Rosdakarya. 